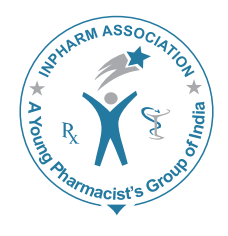

\title{
JVP
}

\section{Cardioprotective Effects of Lagenaria siceraria Fruit Juice on Isoproterenol-induced Myocardial Infarction in Wistar Rats: A Biochemical and Histoarchitecture Study}

\author{
Upaganlawar A, Balaraman R \\ Pharmacy Department, Faculty of Technology and Engineering, The M. S. University of Baroda, \\ Vadodara, Gujarat, India
}

Address for correspondence: Dr. Aman B Upaganlawar; E-mail: amanrx@yahoo.com

\begin{abstract}
The present study was designed to evaluate the cardioprotective effects of Lagenaria siceraria fruit juice in isoproterenol-induced myocardial infarction. Rats injected with isoproterenol $(200 \mathrm{mg} / \mathrm{kg}$, s.c.) showed a significant increase in the levels of serum uric acid, tissue $\mathrm{Na}^{++}$and $\mathrm{Ca}^{++}$ions and membrane-bound $\mathrm{Ca}^{+2}$-ATPase activity. A significant decrease in the levels of serum protein, tissue $\mathrm{K}^{+}$ion, vitamin $\mathrm{E}$ level, and the activities of $\mathrm{Na}^{+} / \mathrm{K}^{+}$-ATPase and $\mathrm{mg}^{+2}$-ATPase was observed. Isoproterenol injected rats also showed a significant increase in the intensity of lactate dehydrogenase isoenzyme and histopathologic alterations in the heart. Treatment with L. siceraria fruit juice ( $400 \mathrm{mg} / \mathrm{kg} /$ day, p.o.) for 30 days and administration of isoproterenol on $29^{\text {th }}$ and $30^{\text {th }}$ days showed a protective effect on altered biochemical and histopathologic changes. These findings indicate the cardioprotective effect of $L$. siceraria fruit juice in isoproterenol-induced myocardial infarction in rats.
\end{abstract}

Key words: Antioxidant activity, isoproterenol, Lagenaria siceraria, myocardial infarction

\section{INTRODUCTION}

Lagenaria siceraria (LS), commonly known as bottle gourd, is reported in Ayurvedic Pharmacopoeia. Traditionally, the fruit of LS is used for its cardioprotective, cardiotonic, diuretic, and aphrodisiac activities and as an antidote to certain poisons. ${ }^{[1,2]}$ Modern pharmacological studies have shown that fruit of LS possesses various positive effects

\begin{tabular}{|l|l|}
\hline \multicolumn{2}{|c|}{ Access this article online } \\
\hline Quick Response Code: & \\
\hline & Website: \\
\hline & www.jyoungpharm.in \\
& \\
\hline
\end{tabular}

Journal of Young Pharmacists Vol 3 / No 4 in preventing various conditions including pain and inflammation, has diuretic activities, and is also effective in hyperlipidemic condition, ${ }^{[3-5]}$ cardiotoxicity and stress. ${ }^{[6,7]}$

Isoproterenol (ISO), a $\beta$-adrenergic agonist, has been found to produce stress in the myocardium due to the generation of free radicals by its auto-oxidation. Some of the mechanisms proposed to explain ISO-induced damage to cardiac myocytes include hypoxia, coronary hypotension, calcium overload, energy depletion and excessive production of free radicals as a result of catecholamine autoxidation. ${ }^{[8,9]}$ Several natural products are reported to prevent ISO-induced myocardial infarction (MI) due to their antioxidant activity. In our previous study, we had reported the protective effects of Langenaria siceraria fruit juice (LSFJ) in electrocardiographic, hemodynamic, 
endogenous antioxidant status and lipid peroxidation in ISO-induced MI in rats. ${ }^{[10]}$

Till date, no study has been carried out regarding the effect of LSFJ on membrane-bound phosphatases and histopathologic alteration induced by ISO. So, an attempt was made to evaluate the cardioprotective activity of LSFJ in ISO-induced MI by evaluating biochemical and histopathologic changes discussed below.

\section{MATERIALS AND METHODS}

Drugs and chemicals

$( \pm)$-Isoproterenol hydrochloride (ISO) was purchased from Sigma Aldrich Co. (St. Louis, MO, USA). Fresh fruits of LS were collected from a nearby farm at Baroda, Gujarat. All the reagents and chemicals used in the entire study were of analytical grade.

Collection and authentication of Lagenaria siceraria fruits

Fresh fruits of LS were collected from a nearby farm at Baroda. The fruits collected were semi-ripe, bottle shaped, weighed between 500 and $700 \mathrm{~g}$ and of the same plant. The fruit of LS was authenticated by the authority from Botany Department, The M. S. University of Baroda, Vadodara.

\section{Preparation of Langenaria siceraria fruit juice}

Fresh juice of LS was prepared with the help of a juicer without adding water. $250 \mathrm{~g}$ of fresh fruit was chopped into small pieces and $135 \mathrm{ml}$ juice was collected. The juice was filtered with a sterile cloth and the resultant filtrate was used for oral dosing to animals. $10 \mathrm{ml}$ of fresh juice was subjected to drying in a previously dried and weighed Petri dish, the juice was evaporated to complete dryness in a hot air oven $\left(45^{\circ} \mathrm{C}\right)$ and then the weight of Petri dish containing dry residue of juice was taken and milligram equivalent dose of $10 \mathrm{ml}$ juice was calculated by subtracting the initial weight of dried petridish. The same procedure was repeated for six times on different days. It was clear from the mean that $10 \mathrm{ml}$ of juice gives $602.00 \mathrm{mg}$ of total solid residue in dried juice, which is equivalent to $250 \mathrm{~g}$ of fresh fruit of LS. The dose of fresh juice of LS in (ml) equivalent of 100, 200 and $400 \mathrm{mg} / \mathrm{kg} /$ day was administered orally to rats for 30 days.

Fixation of optimum dosage of Langenaria siceraria fruit juice

A pilot study was carried out to establish the optimum dose of the drugs which exhibits maximum cardioprotective effect during 30 days. Rats were treated with LSFJ (100, 200 and $400 \mathrm{mg} / \mathrm{kg} /$ day, p.o.) for 30 days and ISO was administered on $29^{\text {th }}$ and $30^{\text {th }}$ days. At the end of treatment period, serum lactate dehydrogenase $(\mathrm{LDH})$ and creatine phospokinase-MB levels were evaluated. $400 \mathrm{mg} / \mathrm{kg} /$ day, p.o. was found to be the most effective dosage of LSFJ in functional recovery of the above biochemical alterations and this dose was selected for further evaluation in the present study.

Experimental animals

All experiments were carried out on male albino Wistar rats weighing 200-250 g, obtained from in-house animal breeding. They were housed in polypropylene cages $(47 \times 34 \times 20 \mathrm{~cm})$ lined with husk, renewed every $24 \mathrm{~h}$ under a $12: 12 \mathrm{~h}$ light:dark cycle at around $22^{\circ} \mathrm{C}$ and had free access to water and food. The animals were fed on a standard pellet diet (Pranav Agro Industries Ltd., Maharashtra, India). All the protocols of animal experiments were approved by the Institutional Animal Ethics Committee (IAEC) in accordance with the guidelines of Committee for the Purpose of Control and Supervision of Experiments on Animals (CPCSEA), Ministry of Social Justice and Empowerment, Government of India, New Delhi.

\section{Experimental protocol}

Group I: Control rats received distilled water for 30 days and normal saline $\left(1 \mathrm{ml} / \mathrm{kg}\right.$, s.c.) on $29^{\text {th }}$ and $30^{\text {th }}$ days. Group II: Rats received distilled water for 30 days and ISO ( $200 \mathrm{mg} / \mathrm{kg}$, s.c.) in normal saline on $29^{\text {th }}$ and $30^{\text {th }}$ days at an interval of $24 \mathrm{~h}$. Group III: Rats received LSFJ (400 mg/kg/day, p.o.) for 30 days. Group IV: Rats received LSFJ (400 mg/kg/day, p.o.) for 30 days and ISO on $29^{\text {th }}$ and $30^{\text {th }}$ days.

Twenty-four hours after the second injection (i.e. at $48^{\text {th }} \mathrm{h}$ after first injection of ISO) of ISO was given, blood was collected and serum was separated. The animals were sacrificed and the heart was dissected out and weighed. Serum and heart tissue homogenate were used for the estimation of following biochemical parameters.

Assessment of serum uric acid and total protein

On day 31, blood was collected from the retro-orbital plexus under mild ether anesthesia. Serum was separated and the levels of serum uric acid and total protein were determined by using standard kits (Reckon Diagnostic Ltd., Vadodara, Gujarat, India). 


\section{Estimation of vitamin $\mathrm{E}$}

The level of vitamin E was estimated as suggested by Desai. ${ }^{[1]]}$ To $1 \mathrm{ml}$ of homogenate, $1 \mathrm{ml}$ of ethanol was added and thoroughly mixed. $3 \mathrm{ml}$ of petroleum ether was added, shaken rapidly and centrifuged. $2 \mathrm{ml}$ of supernatant was taken and evaporated to dryness. To this, $0.2 \mathrm{ml}$ of bathophenanthroline $(0.2 \%$ 4,6-diphenyl-1,10-phenanthroline in ethanol) was added. The assay mixture was protected from light and $0.2 \mathrm{ml}$ of ferric chloride $(0.001 \mathrm{M})$ was added followed by $0.2 \mathrm{ml}$ of o-phosphoric acid $(0.001 \mathrm{M})$. The total volume was made upto $3 \mathrm{ml}$ with ethanol. The color developed was read at $530 \mathrm{~nm}$. The level of vitamin $\mathrm{E}$ is expressed as $\mu \mathrm{g} / \mathrm{mg}$ protein.

Estimation of membrane-bound phosphatases $\left(\mathrm{Na}^{+/} \mathrm{K}^{+}, \mathrm{Mg}^{++}\right.$and $\mathrm{Ca}^{++}$ATPases)

The sediment after centrifugation of tissue homogenate was resuspended in ice-cold tris buffer $(10 \mathrm{mM}, \mathrm{pH}$ 7.4) to get a final concentration of $10 \% \mathrm{w} / \mathrm{v}$ and was used for the estimation of $\mathrm{Na}^{+} / \mathrm{K}^{+}$-ATPase, ${ }^{[12]} \mathrm{Ca}^{2+}$-ATPase ${ }^{[13]}$ and $\mathrm{mg}^{2+}$-ATPase. ${ }^{[14]}$ Protein was estimated according to the method of Lowery et al. ${ }^{[15]}$

\section{Estimation of $\mathrm{Na}^{+}, \mathrm{K}^{+}$and $\mathrm{Ca}^{++}$levels}

The concentrations of $\mathrm{Na}^{+}$and $\mathrm{K}^{+}$were estimated using commercial kits (Monozyme India Ltd., Secunderabad, India). $\mathrm{Ca}^{++}$in the heart homogenate was measured by the 0 -cresolphthalein complexone method using a reagent kit (Span Diagnostic Ltd., Gujarat, India). In this method, o-cresolphthalein complexone binds to calcium tightly in alkaline solution to form a deeply colored complex, owing to lactone formation in the phthalein part of molecule. ${ }^{[16]}$

\section{Separation of $\mathrm{LDH}$ isoenzymes}

LDH isoenzymes were separated and quantified by agarose gel electrophoresis. ${ }^{[17]}$ Agarose gel (1\%) was prepared and applied immediately to the glass slide. After the agarose gel had set properly, serum samples were applied into wells and separated by electrophoresis. After the run, the gels were removed and stained by using staining solution. The gels were incubated with the staining solution at $37^{\circ} \mathrm{C}$ in the dark for a suitable period (approx. $30 \mathrm{~min}$ ). The separated $\mathrm{LDH}$ isoenzymes appeared as purple bands. The gel was washed with $7.5 \%$ acetic acid and preserved in $5 \%$ acetic acid. The photographs were taken using AlphaEase Fc Imaging system, USA.
Hemotoxylin and eosin staining

After the treatment period, the animals were sacrificed and the organs were excised, blotted free of blood and tissue fluids and preserved in 10\% v/v formal saline solution. The specimens were given for further processing to Baroda Pathological Laboratory, Vadodara, where routine procedure for sectioning, staining and mounting was observed by the laboratory personnel. Briefly, after a week, the tissues were washed thoroughly in repeated changes of $70 \%$ alcohol and then dehydrated in ascending grades of alcohol (70-100\%). After dehydration, the tissues were cleaned in xylene and embedded in paraffin wax. Sections of $5 \mu \mathrm{m}$ thickness were cut with a microtome and taken on glass slides coated with albumin. The sections were deparaffinated in xylene and downgraded through 100, 90, 70, 50,30\% alcohol and then finally in water. The hematoxylin-stained sections were stained with eosin for 2 minutes and were then quickly passed through ascending grades of alcohol, cleaned in xylene and mounted on Canada balsam. The stained sections were examined under Olympus (Magnus MIX series) India Pvt. Ltd. photomicroscope and photographed $(10 \times)$. The pathologist was blinded to the treatment. Analyses of the heart sections were carried out. Briefly, the findings were graded as no changes (A); $(+)$ mild (focal myocyte damage or small multifocal degeneration with slight degree of inflammatory process); $(++)$ moderate (extensive myofibrillar degeneration and/or diffuse inflammatory process); $(+++)$ marked (necrosis with diffuse inflammatory process).

Statistical analysis

Results are presented as mean \pm SEM. Analysis was done using one-way analysis of variance (ANOVA) followed by Bonferroni multiple comparisons using a computer-based fitting program (Prism). Differences were considered to be statistically significant when $P<0.05$.

\section{RESULTS}

Effect of LSFJ on serum uric acid, total protein and vitamin $\mathrm{E}$ levels

ISO injected rats showed a significant increase $(P<0.001)$ in serum uric acid levels and significant decrease $(P<0.001)$ in total protein and tissue vitamin $\mathrm{E}$ levels as compared to control rats. Administration of LSFJ to ISO injected rats (LSFJ + ISO) showed a significant $(P<0.05)$ increase in the total protein level and tissue vitamin $\mathrm{E}$ contents as compared to ISO injected groups. LSFJ administered rats showed decrease in uric acid level compared to ISO injected 
rats, but it was found to be statistically non-significant [Table 1].

\section{Effect of LSFJ on ATPases and electrolytes' levels}

The effects of LSFJ on membrane-bound ATPase and electrolyte levels in normal and ISO injected rats are shown in Figure 1 and Table 2. Rats injected with ISO showed a significant $(P<0.001)$ decrease in $\mathrm{Na}^{+} / \mathrm{K}^{+}$-ATPase and $\mathrm{mg}^{+2}$-ATPase and a significant $(P<0.001)$ increase in $\mathrm{Ca}^{+2}$-ATPase activity as compared to control rats. Treatment with LSFJ in ISO injected rats (LSFJ + ISO) showed a significant $(P<0.05)$ decrease in $\mathrm{Ca}^{+2}$-ATPase as compared to ISO injected group [Figure 1]. ISO injected rats also showed a significant $(P<0.001)$ increase in the levels of tissue sodium and calcium; however, the level of potassium was significantly $(P<0.001)$ decreased compared to normal control rats. Administration of LSFJ for 30 days significantly $(P<0.05)$ improved the level of tissue sodium concentration. However, it showed non-significant effects on calcium and potassium level.

Effect of LSFJ on separation of LDH isoenzymes levels

Agarose gel electrophoretic separation of serum LDH

Table 1: Effect of LSFJ ( $400 \mathrm{mg} / \mathrm{kg} /$ day, p.o.) for 30 days on the levels of uric acid, total protein and vitamin $E$ in the heart of normal and ISO injected rats

\begin{tabular}{lccc}
\hline Groups & $\begin{array}{c}\text { Uric acid } \\
(\mathrm{mg} / \mathrm{dl})\end{array}$ & $\begin{array}{c}\text { Total protein } \\
(\mathrm{mg} / \mathrm{dl})\end{array}$ & $\begin{array}{c}\text { Vitamin E } \\
(\mathrm{mmol} / \mathrm{mg} \text { protein })\end{array}$ \\
\hline Control & $4.89 \pm 0.29$ & $7.34 \pm 0.37$ & $2.02 \pm 0.047$ \\
ISO & $7.78 \pm 0.65^{\# \#}$ & $3.58 \pm 0.65^{\# \#}$ & $1.09 \pm 0.043^{\# \#}$ \\
LSFJ & $4.88 \pm 0.78$ & $7.31 \pm 0.42$ & $2.11 \pm 0.052$ \\
LSFJ + ISO & $6.44 \pm 0.27^{\mathrm{ns}}$ & $5.05 \pm 0.41^{*}$ & $1.27 \pm 0.036^{*}$ \\
\hline
\end{tabular}

Values are expressed as mean \pm SEM $(n=6) .{ }^{\# \prime} P<0.001$ values compared to control groups; $* P<0.05,{ }^{*} P<0.01, * * * P<0.001$ values compared to ISO injected groups

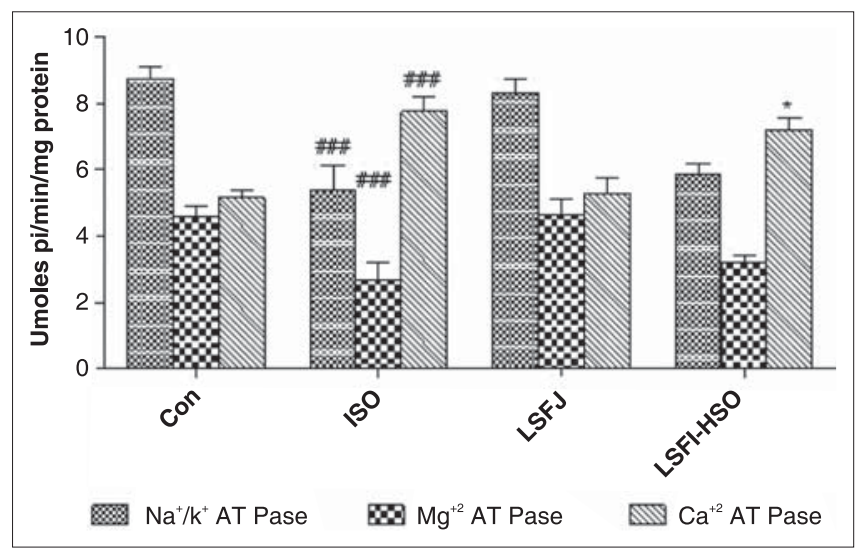

Figure 1: Effect of LSFJ (400 mg/kg/day, p.o.) for 30 days on the activity of $\mathrm{Na}^{+} / \mathrm{K}^{+}$-ATPase, $\mathrm{Mg}^{+2}$-ATPase and $\mathrm{Ca}^{+2}$-ATPase in normal and ISO injected rats. Values are expressed as mean \pm SEM $(n=6)$. ${ }^{\#} P<0.05,{ }^{\#} P<0.01,{ }^{\#} \# P<0.001$ values compared to control groups; ${ }^{\star} P<0.05,{ }^{* \star} P<0.01,{ }^{* \star *} P<0.001$ values compared to ISO injected groups isoenzyme patterns of normal and ISO injected rats is shown in Figure 2. Rats injected with ISO showed an increase in the intensity of LDH-1 and LDH-2 isoenzyme bands compared to control rats. Treatment with LSFJ in ISO injected rats $(\mathrm{LSFJ}+\mathrm{ISO})$ resulted in a decrease in the intensity of LDH-1 isoenzymes compared to ISO injected rats.

\section{Effect of LSFJ on histopathologic alteration}

Light micrograph of ISO injected rats showed necrosis of muscle fibers, inflammatory cell infiltration and edema with fragmentation of muscle fibers [Figure 3 and Table 3] as compared to control group. Treatment with LSFJ in ISO treated rats (LSFJ + ISO) showed moderate degree of edema, necrosis and inflammatory cells compared to ISO injected rats. Rats treated with LSFJ alone did not show any significant alteration in normal architecture of cardiac tissue.

\section{DISCUSSION}

Phytopharmaceuticals are gaining importance in allopathic as well as in traditional medicine owing to their non-addictive and less toxic nature. Novel antioxidants may offer an

Table 2: Effect of LSFJ (400 mg/ kg/day, p.o.) for 30 days on the levels of sodium, potassium and calcium in the heart of normal and ISO injected rats

\begin{tabular}{|c|c|c|c|}
\hline Groups & Sodium $\left(\mathbf{N a}^{+}\right)$ & Potassium $\left(\mathrm{K}^{+}\right)$ & Calcium $\left(\mathrm{Ca}^{++}\right)$ \\
\hline Control & $6.088 \pm 0.125$ & $8.978 \pm 0.164$ & $10.81 \pm 0.107$ \\
\hline ISO & 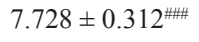 & $6.162 \pm 0.216^{\# \# \# ~}$ & 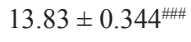 \\
\hline LSFJ & $6.087 \pm 0.131$ & $8.962 \pm 0.118$ & $10.72 \pm 0.221$ \\
\hline $\mathrm{LSFJ}+\mathrm{ISO}$ & $7.573 \pm 0.115^{\mathrm{ns}}$ & $6.838 \pm 0.149 *$ & $13.02 \pm 0.133^{\mathrm{ns}}$ \\
\hline
\end{tabular}

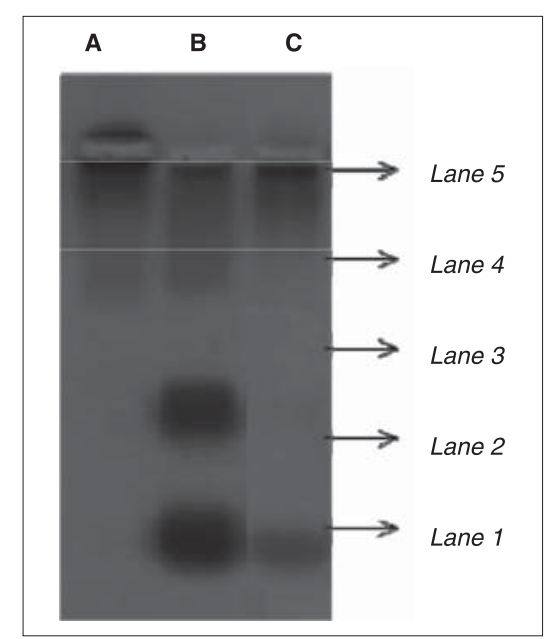

Figure 2: Effect of LSFJ (400 mg/kg/day, p.o.) for 30 days on LDH isoenzyme pattern in normal and ISO injected rats (A: Control, $\mathrm{B}$ : ISO, C: LSFJ + ISO) (lane 1, LDH-1; lane 2, LDH-2; lane 3, LDH-3; lane 4, LDH-4; lane 5, LDH-5) 

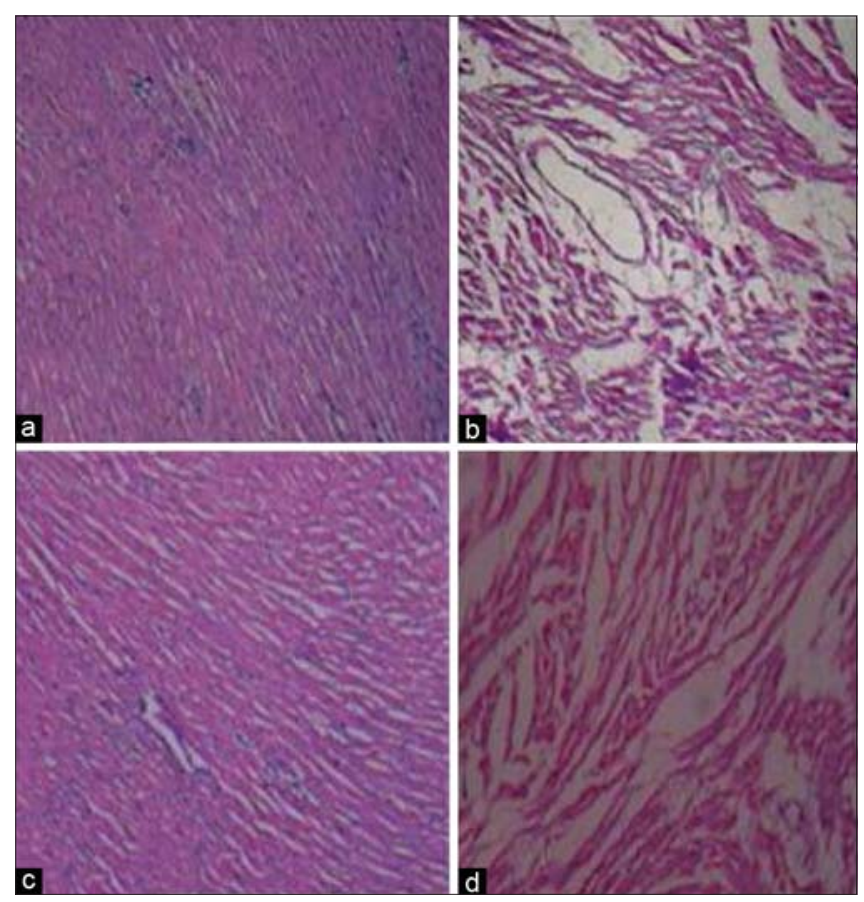

Figure 3: Effect of LSFJ (400 mg/kg/day, p.o.) for 30 days on histopathologic alteration in normal and ISO injected rats (a: Control rats; b: ISO injected rats showing necrosis, edema and inflammatory infiltrations; c: LSFJ alone treated rats; d: LSFJ + ISO treated rats)

Table 3: Effect of LSFJ (400 mg/kg/day, p.o.) for 30 days on the degree of histological changes in normal and ISO injected rats

\begin{tabular}{lccc}
\hline Groups & Necrosis & Edema & Inflammatory cells \\
\hline Control & $\mathrm{A}$ & $\mathrm{A}$ & $\mathrm{A}$ \\
ISO & +++ & +++ & ++ \\
LSFJ & $\mathrm{A}$ & $\mathrm{A}$ & $\mathrm{A}$ \\
LSFJ + ISO & ++ & +++ & + \\
\hline
\end{tabular}

Photomicrographs were used to evaluate the damage in the heart tissues. (A) No change, $(+++)$ marked changes, $(++)$ moderate changes, $(+)$ mild changes

effective and safe means of counteracting some of the problems and boosting the body's defense against free radicals and cardiovascular diseases. ${ }^{[18]}$ Many dietary antioxidants and some non-nutrient based antioxidants from plants such as garlic, green tea, anthocyanins in red berries, lycopene in tomatoes, red and white wines from grape seeds are increasingly being recognized as potential health promoters in reducing the risk of cardiovascular disease. ${ }^{[19]}$

In the present study, a significant increase in serum uric acid levels and a decrease in total protein levels were observed in ISO injected rats, which is in line with the previous reports. ${ }^{[20]}$ Large group studies have shown that uric acid is an important independent risk factor for cardiovascular mortality and in the development of MI. ${ }^{[2]]}$ In hypoxic tissue, ATP depletion occurs, causing accumulation of hypoxanthine. When tissues are disturbed, the enzyme xanthine dehydrogenase is converted to xanthine oxidase by the oxidation of essential -SH groups. Xanthine oxidase catalyzes the conversion of hypoxanthine to xanthine, uric acid and superoxide. ${ }^{[22]}$ This could be one of the reasons for the elevated levels of serum uric acid in ISO injected rats. A decrease in the level of serum total proteins in ISO injected rats could be due to increased free radical production by ISO. Administration of LSFJ did not show significant improvement in serum uric acid level, whereas it showed improvement in serum protein levels as compared to ISO injected rats.

Vitamin $\mathrm{E}$ is a major lipid-soluble non-enzymatic antioxidant present in cell membranes and lipoproteins and protects against oxidative modification. ${ }^{[23]}$ The observed decrease in the vitamin $\mathrm{E}$ level in the present study might be due to increased utilization for the neutralization of ISO-mediated free radicals and lipid peroxidation. Administration of LSFJ improved the level of vitamin E which might be due to its antioxidant activity.

ATPases play a significant role in the contraction and relaxation of the cardiac muscle by maintaining the normal ion levels inside the myocyte. In the present study, ISO injected rats showed a significant decrease in $\mathrm{Na}^{+} / \mathrm{K}^{+}$-ATPase and $\mathrm{Mg}^{2+}$-ATPase activities and correspondingly $\mathrm{Ca}^{2+}$-ATPase activity was increased. The changes in the ATPase activity are in line with the previous reports. ${ }^{[24]} \mathrm{Na}^{+} / \mathrm{K}^{+}$-ATPase is a lipid-dependent enzyme containing sulfhydryl $(-\mathrm{SH})$ group. Oxidants are known to initiate lipid peroxidation and thus destroy phospholipids which are required for the normal activity of membrane-bound protein. Increased in lipid peroxidation and decrease in the phospholipid content in myocardium following ISO injection was reported in our previous study. ${ }^{[25,26]}$ This could be the reason for alteration in the ATPase activity.

Results of the present study also displayed enhanced activity of $\mathrm{Ca}^{2+}$-ATPase; this may be due to the activation of adenylate cyclase activity. ISO-induced MI has been reported to enhance adenylate cyclase activity, resulting in increased formation of cAMP. ${ }^{[27]}$ This may be one of the reasons for enhanced $\mathrm{Ca}^{2+}$-ATPase activity and thereby increased $\mathrm{Ca}^{2+}$ level. Calcium overload in the myocardial cells during ischemia activates the $\mathrm{Ca}^{2+}$-dependant ATPase of the membrane, depleting high high-energy phosphate stores, thereby indirectly inhibiting $\mathrm{Na}^{+}$and $\mathrm{K}^{+}$transport and inactivating $\mathrm{Na}^{+} / \mathrm{K}^{+}$-ATPase. ${ }^{[20]}$

In the cell, ATPases are intimately associated with the plasma membrane and participate in the energy-dependent transport of sodium, potassium, magnesium and calcium translocation. ${ }^{[28]}$ An increase in sodium and calcium along with decrease in potassium were observed in ISO injected 
rats. As discussed above, an alteration in ATPase activity brings about a change in the concentration of electrolytes. Treatment with LSFJ in ISO injected rats (LSFJ + ISO) slightly altered the ATPase activity and electrolyte levels, but was found to be statistically non-significant.

$\mathrm{LDH}$ is a cytosolic enzyme existing in five different isoforms (LDH-1-LDH-5). LDH-1 predominates in cardiac tissues. Variation in the serum LDH isoenzyme pattern can be considered as definitive diagnostic criterion for assessing the myocardial damage, as the rate of appearance and disappearance of LDH in the blood indicates the size of infarction. ${ }^{[29]}$ In the present study, an increase in LDH-1 and LDH-2 isoenzyme bands in ISO injected rats was observed which is supported by previous findings. ${ }^{[30]}$ Administration of LSFJ significantly decreased the intensity of LDH-1 isoenzyme, suggesting its membrane stabilizing activity.

Biochemical findings were further confirmed by histopathologic studies. Histopathologic examination of myocardial tissue in control rats depicted clear integrity of the myocardial cell membrane. Histopathologic sections of the heart injected with ISO displayed necrosis of muscle fibers with inflammatory cell infiltration, edema and fragmentation of muscle fibers, which indicates involvement of oxidative stress and inflammatory processes in ISO induced myocardial injury. Administration of LSFJ in ISO injected rats (LSFJ + ISO) resulted in moderate changes in histopathologic alterations [Figure 3 and Table 3].

In conclusion, the present study showed the protective effect of LSFJ on ISO-induced MI in rats. These effects might be due to the presence of polyphenolic components in the fruit of LS. Further study is required with higher doses/duration of treatment with LSFJ to confirm its cardioprotective activity.

\section{ACKNOWLEDGMENT}

This research was supported by grants from All India Council for Technical Education (AICTE), New Delhi, in the form of National Doctoral Fellowship (NDF) to the first author.

\section{REFERENCES}

1. Nadkarni KM. Indian Materica Medica, Vol. 1, A.K. Nadkarni, Popular Prakashan; 1992. p. 722-3.

2. Duke JA. Medicinal plants. Science 1985;229:1036-8.

3. Ghule BV, Ghanta MH, Upaganlawar AB, Yeole PG. Analgesic and anti-inflammatory activities of Lagenaria siceraria Stand. fruit juice extract in rats and mice. Pharmacog Mag 2006a;2:232-8.
4. Ghule BV, Ghante MH, Saoji AN, Yeole PG. Diuretic activity of Lagenaria siceraria fruit extract in rats. Indian J Pharm Sci 2006b;69:817-9.

5. Ghule BV, Ghante MH, Saoji AN, Yeole PG. Hypolipidemic and antihyperlipidemic effects of Lagenaria siceraria (mol.) fruit extracts. Indian J Exp Biol 2006c;44:905-9.

6. Deshpande JR, Mishra MR, Meghre VS, Wadodkar SG, Dorle AK. Beneficial effects of Lagenaria siceraria (Mol.) Stand. fruit epicarp in animal models. Indian J Exp Biol 2008;40:234-42.

7. Fard MH, Bodhankar SL, Madhumira D. Cardioprotective activity of fruit of Lagenaria siceraria (Molina) Stanley on Doxorubicin induced cardiotoxicity in rats. Int J Pharmacol 2008;4:466-71.

8. Rona G, Chappel CI, Balazs T, Gaudry R. An infarct-like myocardial lesion and other toxic manifestations produced by isoproterenol in the rat. Arch Pathol 1959;76:443-5.

9. Adameova A, Abdellatif Y, Dhalla NS. Role of excessive amounts of circulating catecholamines and glucocorticoids in stress-induced heart disease. Can J Physiol Pharmacol 2009;87:493-514.

10. Upaganlawar A, Balaraman R. Protective effects of Lagenaria siceraria (Molina) fruit juice in isoproterenol induced myocardial infarction. Int J Pharmacol 2010;6:645-51.

11. Desai ID. Vitamin E analysis methods for animal tissues. Met Enzymol 1984;66:138-47.

12. Bonting SL. Membrane ion transport. In: Pembroski TM, Schmidt TH, Blumchen G, editors. Bio-Behavioral Base of Coronary Heart Disease, Vol 1. London: Wiley Inter Science; 1970. p. 254-363.

13. Hjerken S, Pan H. Purification and characterization of two form of low affinity calcium ion ATPase from erythrocyte membrane. Biochim Biophys Acta 1983;728:281-8.

14. Ohinishi T, Suzuki T, Suzuki Y, Ozawa K. A Comparative study of plasma membrane $\mathrm{Mg}^{2+}$ ATPase activities in normal, regenerating and malignant cells. Biochim Biophys Acta 1982;684:67-4.

15. Lowery OH, Rosenbrough NJ, Farr AI, Randall RJ. Protein measurement with the Folin phenol reagent. J Biol Chem 1951;193:265-75.

16. Devika PT, Prince PSM. (-) Epigallocatechingallate (EGCG) prevents isoproterenol induced cardiac toxicity by stabilizing cardiac marker enzymes and membrane bound ATPases. J Pharm Pharmac 2008a;60:125-33.

17. McKenzie D, Henderson AR. Electrophoresis of lactate dehydrogenase isoenzymes. Clin Chem 1983;29:189-95.

18. Ying W. Deleterious network hypothesis of aging. Med Hypothesis 1997;48:143-8.

19. Wexler BC, Kittinger GN. Myocardial necrosis in rats: Serum enzymes, adrenal steroids and histopathological alterations. Circ Res 1963;13: 159-71.

20. Rajadurai M, Prince PSM. Preventive effect of naringin on cardiac markers, electrocardiographic patterns and lysosomal hydrolases in normal and isoproterenol-induced myocardial infarction in Wistar rats. Toxicology 2007; 230:178-88.

21. Niskanen LK, Laaksonen DE, Nyyssonen K, Alfthan G, Lakka HM, Lakka TA, et al. Uric acid level as a risk factor for cardiovascular and all-cause mortality in middle-aged men: A prospective cohort study. Arch Intern Med 2004;164:1546-51.

22. McCord JM. Free radicals and myocardial ischemia. Free Radic Biol Med 1988;4:9-14.

23. Prabhu S, Jainu M, Sabiths KE, Devi CS. Role of mangiferin on biochemical alterations and antioxidant status in isoproterenol-induced myocardial infarction in rats. J Ethnopharmacol 2006;107:126-33.

24. Upaganlawar A, Gandhi H, Balaraman R. Effect of Vitamin E alone and in combination with lycopene on biochemical and histopathological alterations in isoproterenol induced myocardial infarction in rats. J Pharmacol Pharmacother 2010;1:24-31.

25. Upaganlawar A, Balaraman R. Combined effect of vitamin E and green tea on serum and heart lipids, lipid metabolizing enzymes and histopathological changes in isoproterenol induced myocardial infarction. Scienta Pharmaceutica 2009;77:791-803.

26. Upaganlawar A, Gandhi C, Balaraman R. Effect of green tea and vitamin E combination in isoproterenol induced myocardial infarction in rats. Plant Foods Hum Nutr 2009;64:75-80. 
27. Subash D, Narinder KK, Nityanand S. Effect of isoprenalin on lipid profile and cardiac enzymes in rats. Indian J Exp Biol 1978;16:376-8.

28. Mourelle M, Franco MT. Erythrocytes defects precede the onset of CCl4 induced liver cirrohsis: Protection of silymarin. Life Sci 1991;48:1083-90.

29. Trofimov GA, Alu B, Polozhentesv SD. Importance of determination of the content of lactate dehydrogenase and its isoenzymes in patients with myocardial infarction complicated by rupture of the heart. Kardiologiia 1975;15:82-4.

30. Priscilla DH, Prince PSM. Cardioprotective effect of gallic acid on cardiac troponon-T, cardiac marker enzymes, lipid peroxidation products and antioxidants in experimentally induced myocardial infarction in Wistar rats. Chem Biol Interact 2009;179:118-24.

How to cite this article: Upaganlawar A, Balaraman R. Cardioprotective effects of Lagenaria siceraria fruit juice on isoproterenol-induced myocardial infarction in wistar rats: A biochemical and histoarchitecture study. J Young Pharmacists 2011;3:297-303.

Source of Support: All India Council for Technical Education (AICTE), New Delhi, in the form of National Doctoral Fellowship (NDF) to the first author.,Conflict of Interest: None declared.

Announcement

\section{iPhone App}

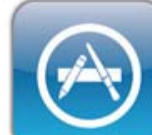

Download

iPhone, iPad application
A free application to browse and search the journal's content is now available for iPhone/iPad. The application provides "Table of Contents" of the latest issues, which are stored on the device for future offline browsing. Internet connection is required to access the back issues and search facility. The application is Compatible with iPhone, iPod touch, and iPad and Requires iOS 3.1 or later. The application can be downloaded from http://itunes.apple.com/us/app/medknow-journals/ $\mathrm{id} 458064375$ ? $\mathrm{s}=1 \& \mathrm{mt}=8$. For suggestions and comments do write back to us. 